\title{
Åpent nummer om profesjonsetikk
}

\author{
May Thorseth, Siri Granum Carson og Allen Alvarez
}

Dette nummeret av tidsskriftet er et åpent nummer der fire av fem bidrag handler om profesjonsetikk. Ett av disse drøfter profesjonsetikk mer generelt, mens de andre tre fokuserer på bestemte profesjoner. Det ene bidraget drøfter spionvirksomhet, mens de andre to ser på toppfotball og global helseetikk. I tillegg har vi et bidrag som sammenlikner etikk og identitetsbygging innenfor ulike nasjonale kontekster. Nedenfor følger en kort beskrivelse av de fem bidragene.

Den første artikkelen i dette nummeret er Andreas Eriksens "What is professional integrity?" Her undersøker Eriksen begrepet “integritet”, med sikte på å finne ut hvorfor begrepet står så sentralt i profesjonslæren og etikken. Eriksen identifiserer to konkurrerende integritetsbegreper, og kritiserer begge. På grunnlag av denne kritikken lanserer han en tredje tolkning, der profesjonell integritet forstås som det å leve opp til bestemte forventninger om hva som er god praksis innenfor en profesjon.

Neste bidrag av Ingeborg Grønning, "Being a good spy: Legitimizing access to web-based observation", diskuterer observasjon av lukkede fora på Internett og relevansen av observasjon som metodologisk tilnærming. Forfatteren reflekterer over sin egen observasjon av et slikt forum og retter et kritisk søkelys mot den valgte metoden, bl.a. på grunnlag av negative reaksjoner fra noen av forskningssubjektene på forskerens tilstedeværelse i forumet. I lys av standarder for god forskning av høy kvalitet, diskuterer forfatteren alternativer til den valgte metoden og tar utgangspunkt i komplekse forskningsetiske problemstillinger i diskusjon mellom forskeren og forskningssubjektene. Informert samtykke er her viet spesiell oppmerksomhet. I spørsmålet om informert samtykke begrunner forfatteren hvorfor fokus på hvorvidt slik deltakelse er skadelig for deltakerne er viktigere enn skillet privat/offentlig.

Det tredje bidraget av Lars Tore H. Ødegård og Gunnar Breivik med tittelen "Hvor moralsk tenker fotballspillere? - en empirisk studie av toppfotball" handler om det økende prestasjonskravet i toppfotball som forfatterne mener fører til en svekkelse av fair play-holdninger. Det empiriske grunnlaget for studien tar utgangspunkt i en topp- og en breddeklubb, der forfatterne tar utgangspunkt i moralske dilemmaer som spillerne opplever på banen. Forfatterne finner store forskjeller mellom topp- og breddefotballen. På grunnlag av de empiriske funnene identifiserer og diskuterer forfatterne faktorer som bidrar til umoralsk opptreden i toppfotballen.

Den fjerde artikkelen i profesjonsetikk-delen av nummeret er skrevet av Odin Lysaker: "Å leve et menneskeverdig liv. Martha Nussbaums globale helseetikk". Forfatteren analyserer her to ulike forståelser av helsebegrepet, der det ene legger vekt på jus og menneskerettigheter, mens det andre legger vekt på etikk og 
menneskeverd. Den siste forståelsen støttes av Nussbaums globale helseetikk og hennes kapabilitetstilnærming. Lysaker gir i artikkelen støtte til denne forståelsen av global helse, og argumenterer for at en slik tilnærming er godt egnet for FNs nye utviklingsagenda, The Post-2015 Development Agenda.

Den femte og siste artikkelen i dette nummeret hører til i den åpne delen, og er skrevet av Jeremiah Lasquety-Reyes og Allen Alvarez: "Ethics and collective identity building: Scandinavian semicommunication and the possibilities of Philippine ethics". Her spør forfatterne hvordan nasjonale samfunn skal bygge legitime og inkluderende kollektive identiteter i samfunn som er kulturelt og språklig mangfoldig. Den filippinske konteksten analyseres langs tre akser: (1) etniske og språklige forskjeller; (2) historisk påvirkning av fremmede kulturer; (3) den språklige dominansen av Tagalog-språket. I diskusjonen av ulike strategier for å oppnå legitim og inkluderende kollektiv identitet, gir forfatterne et forsvar av den strategien som i størst grad likestiller og tilgodeser alle kulturer som deltar i dialogen. Den identifiseres med Philippine ethics, til forskjell fra Pilipino og Filipino ethics. Et viktig poeng er å utfordre den dominerende status quo med Filipino/Tagalog-dominans. Som en del av analysen trekker forfatterne også tråder til det de omtaler som skandinavisk semi-kommunikasjon.

God lesning fra redaktørene!

\section{Acknowledgements}

The editors wish to thank our expert reviewers for this issue. Your careful reading of the submissions and your excellent recommendations have significantly enhanced the quality of the papers we publish. 